\title{
PENGGUNAAN MEDIA PAPAN CATUR MANIPULATIF UNTUK MENINGKATKAN HASIL BELAJAR MATEMATIKA SISWA KELAS XI.MIPA.1
}

\author{
Risnita \\ Guru Matematika SMAN 1 Pangkalan Kerinci Kabupaten Pelalawan \\ risnitamath@gmail.com
}

\begin{abstract}
ABSTRAK: Penelitian ini berawal dari rendahnya hasil belajar matematika peserta didik. Hal ini terlihat pada ulangan harian peserta didik yang berada di bawah Kriteria Ketuntasan Minimal (KKM). Salah satu penyebabnya adalah rendah pemahaman konsep matematika. Pemahaman konsep yang rendah disebabkan materi matematika masih dirasakan abstrak oleh peserta didik. Konsep matematika yang abstrak bagi peserta didik akan menjadi mudah dipahami apabila pembelajaran menggunakan media pembelajaran. Pembelajaran yang dilaksanakan adalah penemuan terbimbing menggunakan media papan catur manipulatif. Penelitian ini bertujuan untuk mengetahui peningkatan hasil belajar peserta didik kelas XI MIPA 1 SMAN 1 Pangkalan Kerinci dan dilakukan dalam dua siklus yang terdiri dari perencanaan, pelaksanaan tindakan, pengamatan dan refleksi. Data penelitian yang dikumpulkan adalah data hasil belajar dan catatan lapangan. Data yang terkumpul dianalisis secara deskriptif. Hasil penelitian ini menunjukkan bahwa penggunaan media papam catur manipulate dengan metode terbimbing dapat meningkatkan hasil belajar. Hasil belajar peserta didik dari siklus I dan siklus II mengalami peningkatan sebesar 36,11\%. Berdasarkan temuan penelitian, dapat disimpulkan bahwa penggunaan media papam catur manipulate dengan metode terbimbing dapat meningkatkan hasil belajar pada materi transformasi geometri.
\end{abstract}

Kata kunci : Hasil belajar, Penemuan Terbimbing dan Media Catur Manipulasi 


\title{
THE USE OF MANIPULATIVE MEDIA TO IMPROVE MATHEMATICS LEARNING OUTCOME OF STUDENT XI.MIPA.1
}

\begin{abstract}
This research starts from the low results of learning mathematics students. This can be seen in the daily test of students who are below the Minimum Completion Criteria (MCC). One reason is a low understanding of mathematical concepts. Low understanding of concepts is due to the fact that mathematics is still abstracted by students. Abstract mathematical concepts for students will be easily understood if learning uses learning media. Learning carried out is discovery learning using manipulative chessboard media. This study aims to determine the improvement in learning outcomes of students of class XI MIPA 1 SMAN 1 Pangkalan Kerinci and conducted in two cycles consisting of planning, action, observation and reflection. The research data collected is data on learning outcomes and field notes. The collected data was analyzed descriptively. The results of this study indicate that the use of manipulate chess shooting media with discovery learning methods can improve learning outcomes. The learning outcomes of students from the first cycle and second cycle increased by $36.11 \%$. Based on the research findings, it can be concluded that the use of manipulate chess shooting media with guided methods can improve learning outcomes on the subject of geometric transformation.
\end{abstract}

Keywords : Learning outcomes, discovery learning and Media Chess Manipulation

\section{PENDAHULUAN}

Pada saat ini Ilmu Pengetahuan dan Teknologi (IPTEK) berkembang pesat. Perkembangan ini memungkinkan semua pihak dapat memperoleh informasi dengan cepat dan mudah. Perkembangan IPTEK dapat digunakan peserta didik untuk membantu proses belajarnya. Agar peserta didik mampu menggunakannya maka diperlukan keterampilan memperoleh, mengolah dan menyimpan informasi. Keterampilan ini dapat dikembangkan melalui belajar matematika.

Tujuan pembelajaran matematika adalah agar peserta didik memiliki kemampuan antara lain: memahami konsep matematika, menjelaskan keterkaitan antar konsep dan mengaplikasikan konsep atau algoritma secara luwes, akurat, efisien dan tepat dalam pemecahan masalah; menggunakan penalaran pada pola dan sifat, melakukan manipulasi matematika dalam membuat generalisasi, menyusun bukti atau menjelaskan gagasan dan 
pernyataan matematika; memecahkan masalah yang meliputi kemampuan memahami masalah, merancang model matematika, menyelesaikan model dan menafsirkan solusi yang diperoleh; mengkomunikasikan gagasan dengan simbol, tabel, diagram atau media lain untuk memperjelas keadaan atau masalah; memiliki sikap menghargai kegunaan matematika dalam kehidupan, yaitu memiliki rasa ingin tahu, perhatian dan minat dalam matematika, serta sikap ulet dan percaya diri dalam pemecahan masalah (BSNP, 2006).

Keterampilan yang diperlukan pada pada saat ini sesuai dengan tujuan pembelajaran. Tujuan pembelajaran matematika dapat tercapai jika proses pembelajaran dikelola dengan baik. Guru memiliki peran yang sangat penting dalam mengelola proses pembelajaran. Menurut Yamin dan Bansu (2009) pengelolaan proses pembelajaran merupakan salah satu komponen yang mempengaruhi keberhasilan pembelajaran. Indikator keberhasilan pembelajaran adalah seberapa baik hasil belajar yang dicapai peserta didik setelah mengikuti proses pembelajaran. Hasil belajar akan baik apa pemahaman konsep matematika benar. Kerjasama antara guru dan peserta didik dalam pembelajaran dapat membantu tujuan pembelajaran matematika. Guru harus selalu menciptakan proses pembelajaran yang mampu membuat peserta didik aktif dalam belajar dengan menerapkan metode pembelajaran yang sesuai. Peserta didik harus aktif dalam pembelajaran sehingga interaksi guru dan peserta didik dapat terjalin dengan baik. Namun kenyataan yang ditemui di Sekolah Menengah Atas Negeri (SMAN) 1 Pangkalan Kerinci khususnya di kelas XI.MIPA.1 pemahaman konsep peserta didik masih rendah. Hal ini berdampak pada hasil belajar matematika peserta didik.Hasil belajar peserta didik kelas XI.MIPA.1 pada mata pelajaran matematika dengan jumlah peserta didik 38 orang dan KKM 70 pada semester I Tahun 2018 SMAN I Pangkalan Kerinci. Sebanyak 89,47\% peserta didik tidak tuntas menjawab untuk KD.3.1 dan $68,42 \%$ untuk KD 3.4. Belum mencapai batas kriteria ketuntasan belajar ideal minimum $75 \%$ (Wina, 2008).

Ketidaktuntasan peserta didik menjawab, dilihat dari jawaban yang diberikan peserta didik pada saat ulangan harian tidak sesuai dengan konsep materi yang dipelajari. Peserta didik belum mampu menyelesaikan masalah dengan langkah-langkah yang benar dan jawaban sebagian besar mengandung perhitungan yang salah, bahkan beberapa peserta didik tidak menjawab sama sekali. Padahal soal yang diberikan bentuknya sama dengan yang dijelaskan dan belum dikombinasikan dalam bentuk lain.

Hasil wawancara peneliti dengan peserta didik, $80 \%$ peserta didik beralasan lupa dengan konsep yang diberikan.Pada umumnya peserta didik menganggap mata pelajaran matematika merupakan mata pelajaran yang sulit dimengerti. Peserta didik berpendapat 
bahwa matematika hanya pelajaran yang terdiri dari berbagai rumus yang rumit untuk dipahami serta jauh dari kehidupan.

Salah satu materi yang banyak menggunakan rumus-rumus adalah transformasi geometri.Sering peserta didik mengeluh apabila sudah mulai masuk pada materi pokok ini, karena penyelesaian banyak rumus-rumus harus dihapal.Peserta didik masih banyak yang belum mampu menyelesaikan berbagai macam soal transformasi geometro dengan alasan terlalu banyak aturan dan konsep trigonometri dan matriks yang harus dipahami.

Usaha yang telah dilakukan guru untuk menanamkan konsep matematika ada dengan mengajak peserta didik secara bersama-sama menemukan konsep-konsep dalam matematika.Selain itu diskusi dan pemberian tugas.Upaya lainnya yaitu membagi peserta didik dalam beberapa kelompok agar peserta didik dapat berdiskusi, saling bertukar fikiran dalam menyelesaikan masalah.Namun upaya yang penulis lakukan belum mampu meningkatkan hasil belajar matematika peserta didik.

Guru berkewajiban untuk menerapkan suatu metode pembelajaran yang melibatkan peserta didik secara aktif. Diharapkan peserta didik tertarik mengikuti proses pembelajaran secara aktif, sehingga hasil belajar peserta didik dapat ditingkatkan. Guru harus menyadari bahwa peserta didik mempunyai kemampuan yang berbeda-beda, baik dalam hal memahami, mengerti, mampu menganalisis unsur-unsur yang ada dalam matematika. Banyaknya unsur-unsur yang ada dalam rumus matematika dan penggunaan simbol-simbol yang bervariasi menuntut peserta didik untuk lebih memusatkan fikiran agar dapat menguasai konsep dalam matematika tersebut.

Guru sebagai salah satu kunci utama dalam memajukan pendidikan harus mampu menggunakan berbagai metode pembelajaran. Proses pembelajaran harus lebih menarik perhatian peserta didik sehingga berdampak pada peningkatan hasil belajar peserta didik khususnya pada pembelajaran matematika. Perubahan yanh harus dilakukan adalah penerapan pembelajaran yang diharapkan mampu menuntun peserta didik untuk melakukan penemuan jawaban soal-soal tranformasi geometri.Salah satu alternatif metode pembelajaran yang dapat digunakan yakni metode penemuan terbimbing.Di samping dapat mengembangkan kemampuan kognitif peserta didik, metode ini juga dapat menumbuhkan aktivitas interaksi peserta didik baik dengan guru maupun antar peserta didik.

Marzano (1992) dalam Markaban (2006) menyatakan bahwa metode penemuan terbimbing memiliki kelebihan sebagai berikut; (1) peserta didik dapat berpartisipasi aktif dalam pembelajaran yang disajikan; (2) menumbuhkan sekaligus menanamkan sikap menemukan (mencari-temukan); (3) mendukung kemampuan problem solving peserta didik; (4) memberikan wahana interaksi antar peserta didik, maupun peserta 
didik dengan guru, dengan demikian peserta didik juga terlatih untuk menggunakan bahasa Indonesia yang baik dan benar; dan (5) materi yang dipelajari dapat mencapai tingkat kemampuan yang tinggi dan lebih lama membekas karena peserta didik dilibatkan dalam proses menemukannya.

Metode penemuan terbimbing dapat digunakan untuk penyampaian topik-topik matematika. Metode ini dalam proses pembelajaran memungkinkan peserta didik menemukan sendiri pola-pola atau struktur-struktur matematika dengan bimbingan guru dan pengalaman-pengalaman proses pembelajaran yang lampau. Diharapkan peserta didik akan memahami konsep transformasi geometri lebih baik, ingat lebih lama dan mampu menggunakannya ke dalam konteks yang lain. Selain itu diharapkan peserta didik akan bergairah untuk mempelajari matematika dan akan membawa mereka ingin mengetahui lebih lanjut hubungan-hubungan yang lain.

Herman (2001) memaparkan tentang kekuatan metode penemuan terbimbing yaitu;

(1) peserta didik ikut berpartisipasi secara aktif di dalam kegiatan belajarnya, sebab ia berfikir, tidak sekedar mendengarkan informasi; (2) peserta didik benar-benar dapat memahami suatu konsep atau rumus, sebab peserta didik mengalami sendiri proses untuk mendapatkan konsep atau rumus itu; (3) metode ini memungkinkan sikap ilmiah dan menimbulkan semangat ingin tahu dari para peserta didik; (4) dengan merasa menemukan sendiri, peserta didik merasa puas dan dengan demikian kepuasan mental sebagai nilai intrinsik terpenuhi. Hal ini mengakibatkan peserta didik ingin menemukan lebih lanjut; (5) dengan metode penemuan terbimbing, guru tetap mempunyai kontak pribadi dengan murid; (6) terdapat bukti bahwa peserta didik-peserta didik yang memperoleh pengetahuan melalui metode penemuan adalah lebih mampu mentransfer pengetahuannya ke berbagai konteks; dan (7) metode ini membatasi guru untuk menambah materi baru, bila ternyata peserta didik belum memahami materi yang sedang dipelajari.

Proses penemuan akan memudahkan peserta didik dengan bantuan media pembelajaran. Penggunaan media dapat menjadikan penemuan konsep matematika menjadi lebih menarik dan berkesan, sehingga pengalaman belajar dirasakan peserta didik lebih konkret. Media yang digunakan merupakan benda yang konkrit yang dapat membantu siswa memahami materi pelajaran dan membuat pelajaran tersebut lebih menarik dan berkesan, sehingga pembelajaran bisa dirasakan siswa lebih menyenangkan dan tidak membosankan. Selain itu penggunaan media bisa mempercepat proses pembelajaran.

Berdasarkan hal tersebut, guna meningkatkan hasil belajar peserta didik, penulis tertarik untuk menerapkan dan melakukan penelitian tentang metode penemuan 
terbimbing dengan menggunakan media catur manipulatif pada proses pembelajaran matematika pokok bahasan transformasi geometri.

\section{METODE}

Penelitian ini merupakan penelitian tindakan kelas (PTK), karena merupakan penelitian tindakan yang dilakukan dengan tujuan untuk memperbaiki kualitas proses pembelajaran dan hasil belajar matematika peserta didik.

Penelitian ini dilaksanakan di kelas XI.MIPA.1 SMAN 1 Pangkalan Kerinci Kabupaten Pelalawan Propinsi Riau, pada semester satu tahun ajaran 2018/2019. Penelitian disesuaikan dengan jadwal pelajaran di sekolah, dengan waktu pertemuan dua kali dalam satu minggu. Penelitian akan terdiri dari 2 siklus, untuk masing-masing siklus kegiatan dirinci menjadi langkah-langkah sebagai berikut :

Daur ulang dalam penelitian tindakan diawali dengan perencanaan tindakan, penerapan tindakan, mengobservasi dan mengevaluasi proses dan hasil tindakan, dan melakukan refleksi.

Data tentang peningkatan hasil belajar peserta didik diperoleh melalui tes hasil belajar matematika peserta didik. Tes yang dilakukan merupakan tes untuk mengukur kemampuan pemahaman konsep matematika peserta didik pada materi pokok tranformasi geometri. Penilaian dilakukan dengan menggunakan rubrik analitik sebagai berikut :

Tabel 1. Kriteria Skor Kemampuan Pemahaman Konsep

Skala
Kriteria/Sub Kriteria
1. Mendefinisikan Konsep
- Menuliskan konsep
2. Mengidentifikasi Konsep
- Menjelaskan tentang ciri- ciri konsep
3. Mengenali prosedur
- Mengenali urutan perhitungan yang benar
dalam proses penemuan
4. Menarik Kesimpulan


- Mendeskripsikan hasil penemuan secarajelas tentangkonsep

trigonometri

\begin{tabular}{cc}
\hline Jumlah Skor & 16 \\
\hline Skor Maksimum & \\
\hline Nilai &
\end{tabular}

Diadaptasi dari Pusat Pengembangan Penataran Guru Matematika (P4TK) Yogyakarta, 2004.

Tabel 2. Rubrik Skala Penilaian Kemampuan Pemahaman Konsep Untuk Setiap Indikator

\begin{tabular}{cc}
\hline Respon Peserta didik & Skala \\
\hline Jawaban benar dan menunjukkan alasan berdasarkan pengetahuan matematika & 4 \\
yang berhubungan dengan tugas & \\
\hline Jawaban benar, ada alasan tetapi ada sedikit jawaban yang salah & 3 \\
\hline kawaban benar tetapi tidak ada alasan, atau pun alasan yang diberikan masih & 2 \\
\hline kawaban ada tetapi salah bahkan tidak menunjukkan pengetahuan matematika & 1 \\
yang berhubungan dengan tugas & 0 \\
\hline Jawaban tidak ada
\end{tabular}

Diadaptasi dari Pusat Pengembangan Penataran Guru Matematika (P4TK) Yogyakarta, 2004.

Untuk kemampuan pemecahan masalah, pada kriteria 1 diberi bobot 1 , kriteria 2 diberi bobot 2, kriteria 3 diberi bobot 1 , kriteria 4 diberi bobot 2 . Skor yang diperoleh $=$ tingkat $\mathrm{x}$ bobot. Nilai siswa diperoleh dengan perbandingan skor total dengan skor maksimum yang dikonversikan ke dalam skala $0-100$.

Data yang dikumpulkan dalam penelitian yaitu data kemampuan pemahaman konseppada siklus I dan siklus II.

Teknik analisis data yang dilakukan adalah dengan analisis secara deskriptif. Analisis ini bertujuan untuk melakukan tindakan perbaikan yang dilakukan pada siklus selanjutnya. Siswa dikatakan telah berhasil memahami materi pembelajaran jika dia mencapai kompetensi minimal $75 \%$. 


\section{HASIL DAN PEMBAHASAN}

\section{Siklus I}

Selama siklus I, peneliti dibantu oleh observer mengamati jalannya pembelajaran penggunaan media papan catur manipulatif melalui penerapan metode penemuan terbimbing. Hal yang diamati meliputi aktivias guru dan aktivitas peserta didik.

Hasil belajar peserta didik pada penelitian ini dilihat dari skor pemahaman konsep matematika pada tes yang dilaksanakan di akhir siklus I. Penilaian kompetensi pengetahuan dilakukan sesuai dengan kriteria dan skala yang telah ditetapkan. Hasil belajar peserta didik untuk kompetensi pengetahuan pada siklus I dapat dilihat pada tabel 3 .

Tabel 3. Hasil Belajar Kompetensi Pengetahuan Siklus I

\begin{tabular}{c|c|c}
\hline Kategori & Jumlah siswa & Persentase \\
\hline Nilai $\square 70$ & 21 & $58,33 \%$ \\
Nilai $<70$ & 15 & $41,67 \%$ \\
\hline
\end{tabular}

Jumlah peserta didik yang tuntas pada siklus pertama sebanyak 21 orang atau 58,33 persen. Artinya, jumlah peserta didik yang nilainya di atas KKM sebanyak 58,33 persen. Jumlah tersebut belum mencapai kriteria yang diharapkan pada penelitian ini yaitu 75 persen. Jumlah peserta didik yang belum mencapai KKM juga masih banyak yaitu 15 orang, hal ini menandakan bahwa perlu perbaikan dalam pembelajaran agar peserta didik bisa lebih memahami materi pokok transformasi geometri.

Peserta didik yang mendapat nilai di bawah KKM disebabkan indikator pemahaman konsep tentang mengidentifikasi konsep dan meyimpulkan tidak dibuat. Dalam penarikan kesimpulan masih memerlukan bimbingan, karena belum semua peserta didik mampu menyimpulkan hasil penemuan metode penemuan terbimbing. Ketika ditanyakan kepada peserta didik, mereka belum terbiasa melakukan pengambilan kesimpulan dalam setiap menjawab soal dan peserta didik masih memandang kesimpulan bukanlah bagian terpenting dalam pemecahan masalah.

\section{Siklus II}

Selama siklus II, peneliti dibantu oleh observer mengamati jalannya pembelajaran penggunaan media papan catur manipulatif melalui penerapan metode penemuan terbimbing. Hal yang diamati meliputi aktivias guru dan aktivitas peserta didik. 
Pada siklus II penilaian hasil belajar juga dilakukan dengan merujuk pada kriteria pemahaman konsep matematika peserta didik. Hasil belajar peserta didik kompetensi pengetahuan pada siklus II dapat dilihat pada tabel 2 .

Tabel 4. Hasil Belajar Kompetensi Pengetahuan Siklus II

\begin{tabular}{rcc}
\hline Kategori & Jumlah Siswa & Persentase \\
& & \\
\hline Nilai $\square 70$ & 34 & $94,44 \%$ \\
Nilai $<70$ & 2 & $5,56 \%$ \\
\hline
\end{tabular}

Jumlah peserta didik yang tuntas pada siklus II sebanyak 34 orang atau 94,44 persen. Artinya, jumlah peserta didik yang tuntas pada pembelajaran sudah lebih dari 75 persen. Kondisi tersebut sudah melebihi kriteria yang ditargetkan pada penelitian ini. Selama pembelajaran siklus II dilaksanakan, secara bertahap, tingkat pemahaman konsep peserta didik semakin meningkat yang ditandai dengan meningkatnya kemampuan peserta didik dalam mendefinisikan konsep yaitu menterjemahkan soal yang diberikan ke dalam simbol matematika dan menuliskannya dalam lembar jawaban. Peserta didik sudah mampu mengidentifikasi konsep yang terlihat pada lembar jawaban dimana peserta didik merinci masing-masing simbol yang diketahui beserta ukuran dan nilainya. Peserta didik sudah memahami konsep transformasi serta penggunaan matriks dalam menyelesaikannya. Hal ini memberikan pengangaruh,jika diberikan soal yang lebih variatif, peserta didik sudah mulai mampu menyelesaikannya dengan benar. Peserta didik dapat mengenali prosedur perhitungan yang benar.

Proses penarikan kesimpulan, peserta didik dapat melakukannya sesuai dengan hasil penemuan yang mereka lakukan dalam menyelesaikan soal yang diberikan. Meski pada penyelidikan, pengidentifikasian konsep dan penarikan kesimpulan masih memerlukan bimbingan, akan tetapi peningkatan kemampuan peserta didik untuk dua kriteria pemahaman konsep tersebut sudah terlihat seperti yang tercantum pada lembar jawaban tes siklus II.

Dari hasil kegiatan pada siklus I dan II peningkatan hasil belajar matematika peserta didik kelas XI MIPA 1 SMAN 1 Pangkalan Kerinci pada materi Transformasi Geometri diperoleh hasil sebagai berikut:

1) Aktivitas Guru

Aktivitas guru selama pembelajaran dari siklus I ke siklus II menunjukan bahwa guru selalu berupaya dan meningkatkan kinerja dalam melakukan pembelajaran untuk 
perubahan demi keberhasilan anak didiknya.

2) Aktivitas Peserta Didik

Aktivitas peserta didik selama proses pembelajaran dari siklus I ke siklus II menunjukan hasil peran peserta didik yang optimal dalam pengelolaan pembelajaran. Dimana peserta didik mempunyai kesadaran untuk mendengarkan dan memperhatikan penjelasan guru dan menyiapkan diri sebelum kegiatan belajar dimulai; peserta didik berdiskusi dan mencari informasi pada aktivitas pembelajaran; peserta didik mempunyai keberanian untuk bertanya dan berpendapat, peserta didik menggunakan media dan sudah menyesuaikan diri dengan metode penemuan terbimbing.

3) Hasil Belajar Matematika

Peningkatan hasil belajar peserta didik yang dilihat dari kemampuan pemahaman konsep matematika peserta didik.

Hasil belajar kompetensi pengetahuan peserta didik pada pembelajaran penggunaaan media papan catur manipulatif dengan menerapkan metode penemuan terbimbing mengalami peningkatan dari siklus I ke siklus II. Jumlah peserta didik yang tuntas pada siklus I sebanyak 21 orang atau 58,33 persen dari 36 peserta didik yang ada di kelas XI MIPA 1 SMAN 1 Pangkalan Kerinci. Pada siklus pertama, hasil belajar yang diperoleh masih kurang dan belum mencapai kriteria yang diharapkan pada penelitian ini. Pada siklus I, masih banyak peserta didik yang belum mampu mendefinisikan dan mengidentifikasi soal-soal transformasi geometri, sehingga mengalami kendala dalam menyelesaikannya. Sedangkan kemampuan mengetahui prosedur perhitungan yang benar sudah cukup baik, namun ada 2 orang peserta didik yang mengalami kendala.

Setelah dilakukan perbaikan sesuai dengan hasil refleksi yang dilakukan, hasil belajar peserta didik mengalami peningkatan pada siklus II, yang mana jumlah peserta didik yang tuntas meningkat sebesar 36,11 persen. Peningkatan hasil belajar belajar dapat juga dilihat pada gambar 1 .

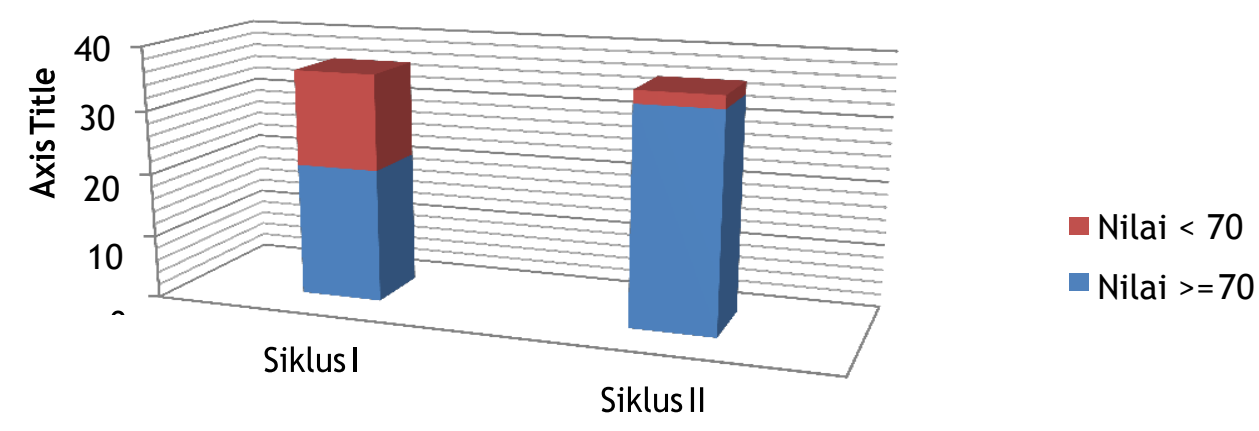

Axis Title

Gambar 1. Perbandingan Hasil Belajar Siklus I dan SiklusII 
Meningkatnya hasil belajar peserta didik untuk kompetensi pengetahuan, dilihat dari semakin baiknya kemampuan peserta didik dalam mendefinisinikan, mengidentifikasikan konsep, mengenali prosedur perhitungan yang benar dan mengambil kesimpulan dari hasil penemuan. Meski demikian, pada kemampuan peserta didik sesuai kriteria pemahaman konsep tersebut, masih perlu diasah lagi, agar peserta didik terbiasa dalam memahami konsep pelajaran matematika.

Nana (2009) mengungkapkan bahwa hasil belajar merupakan kemampuankemampuan yang dimiliki peserta didik setelah menerima pengalaman belajar. Dengan adanya kegiatan belajar akan menghasilkan perubahan peserta didik atau subjek didik. Perubahan positif pada hasil pembelajaran peserta didik pada penelitian merupakan pertanda meningkatnya kemampuan peserta didik setelah menerima pengalaman belajar pada pembelajaran yang menerapkan metode penemuan terbimbing menggunakan media papan catur manipulatif.

\section{SIMPULAN DAN SARAN}

\section{Simpulan}

Setelah melaksanakan penelitian tindakan kelas penggunaan media papan catur manipulative dengan menerapkan metode penemuan terbimbing pada mata pelajaran matematika materi pokok trasformasi geometri kelas XI.MIPA.1 SMAN 1 Pangkalan Kerinci Kabupaten Pelalawan, maka dapat diperoleh kesimpulan sebagai berikut :

1. Penggunaan media papan catur manipulative melalui penerapan metode penemuan terbimbing dapat meningkatkan aktivitas belajar peserta didik kelas XI.MIPA.1 SMAN 1 Pangkalan Kerinci pada materi Transformasi Geometri.

2. Penggunaan media papan catur manipulative melalui penerapan metode penemuan terbimbing hasil belajar peserta didik kelas XI.MIPA.1 SMAN 1 Pangkalan Kerinci pada materi Transformasi Geometri.

\section{Saran}

Berdasarkan hasil penelitian tindakan kelas yang dilaksanakan di kelas XI.MIPA.1 SMAN 1 Pangkalan Kerinci pada tahun pelajaran 2018/2019, dapat dikemukakan saransaran sebagai berikut :

1. Penggunaan media dalam pemebalajaran matematika dapat membuat peserta didik memahami konsep dalam pembelajaran matemaika.

2. Dalam menerapkan pembelajaran dengan metode penemuan terbimbing, sebaiknya guru membuat perencanaan yang matang sehingga pembelajaran berjalan secara 
sistematis. Perencanaan yang matang menjadikan pemanfaatan waktu berjalan efektif.

3. Hasil penelitian ini adalah salah satu alternatif dalam rangka meningkatkan hasil belajar matematika peserta didik. Pada penelitian ini masih sulit untuk mengamati aktivitas peserta didik dalam pembelajaran karena hanya dibantu oleh satu orang observer.

\section{DAFTAR PUSTAKA}

Baharuddin dan Esa, (2007). Teori Belajar dan Pembelajaran. Penerbit Ar-Ruzz Media. Jogyakarta.

Dimyati dan Mudjiono, (2006). Belajar dan Pembelajaran. Depdiknas. Jakarta.

Herman, (2001). Pengembangan Kurikulum Matematika dan Pelaksanaannya di Depan Kelas. Penerbit Usaha Nasional. Surabaya.

Iskandar, (2009). Metodologi Penelitian dan Pendidikan Sosial (Kuantitatif dan Kualitatif). Penerbit Gaung Persada Press. Jakarta.

Ibrahim dan Nana, (2003). Perencanaan Pengajaran. Penerbit Rineka Cipta. Jakarta. Juliati, (2010). Penerapan Pembelajaran Langsung dengan Pendekatan Matematika

Realistik untuk Meningkatkan Aktivitas dan Hasil Belajar Matematika Peserta didik Kelas III SDN 011 Kembang Harum Kecamatan Pasir Penyu. Tesis. Tidak Diterbitkan

Kristina, (2008).Penerapan Metode Penemuan Terbimbing dalam Pembelajaran Matematika di SMAN Padang. Tesis. Tidak Diterbitkan

Lidinillah Muiz Abdul Didin., Alat Peraga Manipulatif Dalam Pembelajaran Pemecahan Masalah Matematika Di Sekolah Dasar.Makalah. http://alat-peragamanipulatif.html

Markaban, (2006). Model Pembelajaran Matematika Dengan Pendekatan Penemuan Terbimbing. Departemen Pendidikan Nasional Pusat Pengembangan dan Penataran Guru Matematika. Yogyakarta.

Martinis, (2009). Strategi Pembelajaran Berbasis Kompetensi. Penerbit Gaung Persada Press Jakarta. Jakarta.

Muliyardi,(2003).Ketika Seni Bercumbu Dengan Matematika.Makalah Disajikan Pada Seminar Nacional Difusi Inovasi Dalam Pembelajaran Matematika Di UPI, 6 September 2003 .

Mulyasa, (2009). Praktek Penelitian Tindakan Kelas. Penerbit Rosdakarya. Bandung. Nasution, (2009). Berbagai Pendekatan dan Proses Belajar Mengajar. Penerbit Bumi

Aksara. Jakarta.

Nana, (2009). Dasar-Dasar Proses Belajar Mengajar. Penerbit Sinar Baru Argensindo. 
Bandung.

, (2006). Penilaian Hasil Proses Belajar Mengajar. Penerbit PT. Rosdakarya. Bandung.

Oemar, (2009). Proses Belajar Mengajar. Jakarta:Penerbit Bumi Pustaka.

Peraturan Menteri Pendidikan Nasional Nomor 22. 2006. BSNP. Jakarta

Program Pasca Sarjana, 2004. Panduan Penulisan Tesis. Program Pasca Sarjana UNP. Padang.

Ratna, (1996). Teori-Teori Belajar. Penerbit Erlangga. Jakarta.

Ruseffendi, (2006). Pengantar Kepada Membantu Guru Mengembangkan Kompetensi Dalam Pengajaran Matematika Untuk Meningkatkan CBSA. Penerbit Tarsito. Bandung.

Saida, (2006). Peningkatan Aktivitas dan Hasil Belajar Matematika Peserta didik SMP Pembangunan dengan Pendekatan Kontekstual Menggunakan Metode Penemuan Terbimbing. Tesis. Tidak Diterbitkan

Sofan dan Iif, (2010). Proses Pembelajaran Kreatif dan Inovatif dalam Kelas. Penerbit Prestasi Pustakaraya. Jakarta.

Sardiman, (2010).Interaksi dan Motivasi Belajar Mengajar.Raja Grafindo Persada. Jakarta.

Suharsimi, (1996). Dasar-Dasar Evaluasi Pendidikan. Penerbit Bumi Aksara. Jakarta.

, (2010).Penelitian Tindakan Kelas. Penerbit Bumi Aksara. Jakarta Syaiful , (2010). Konsep dan Makna Pembelajaran. Penerbit Alfabeta. Bandung.

, (2000). Guru dan Anak Didik Dalam Interaksi Edukasi. Penerbit Rineka Cipta. Jakarta

Thursman, (2000). Belajar Secara Efektif. Puspa Swara. Jakarta.

T. Herman, (2006). Pembelajaran Berbasis Masalah untuk Kerangka Berfikir Matematis Tingkat Tinggi Peserta didik SMP. Disertasi UPI: Tidak diterbitkan.

Trianto, (2009). Mendesain Model Pembelajaran Inovatif-Progresif: Konsep, Landasan, dan Implementasinya Pada Kurikulum Tingkat Satuan Pendidikan (KTSP). Penerbit Kencana. Jakarta.

Turmudi, (2008. Landasan Filsafat dan Teori Pembelajaran Matematika. Penerbit PT Leuser Cipta Pustaka. Jakarta.

Utari, (2005). Pembelajaran Matematika untuk Mendukung Pelaksanaan Kurikulum tahun 2002 Sekolah Menengah. Disajikan dalam Seminar Pendidikan Matematika. UPI: Tidak diterbitkan.

, (2005). Kemampuan Pemahaman dan Penalaran Matematika Peserta didik SMA dikaitkan dengan Kemampuan Penalaran Logika Peserta didik dan Beberapa Unsur Proses Belajar Mengajar. Disertasi. UPI: Tidak diterbitkan.

Walle, (2006). Pengembangan Pengajaran Matematika Sekolah Dasar dan Menengah. Erlangga. Jakarta.

Wina, (2008). Strategi Pembelajaran Berorientasi Standar Proses Pendidikan. Kencana 
Prenada Media Group. Jakarta.

Wina, (2008). Kurikulum dan Pembelajaran. Kencana Prenada Media Group. Jakarta. Winkel, (1989). Psikologi Belajar. Jakarta: Gramedia Widia Sarana.

Yamin, M., dan Bansu I.A., Ansari, (2009), Taktik Mengembangkan Kemampuan Individual Siswa, Gaung Persada Press, Jakarta.

Yatim Riyanto, (2009). Paradigma Baru Pembelajaran. Kencana Prenada Media Group. Jakarta. 